\title{
\begin{tabular}{|l|l|l}
\hline & Jurnal Kependidikan Dasar & $\begin{array}{l}\text { Volume. 2 } \\
\text { Nomor. 1 } \\
\text { Tahun. 2017 }\end{array}$ \\
\hline
\end{tabular}
}

\section{Asesmen Portofolio dalam Pembelajaran IPA di Sekolah Dasar}

\author{
Izza Aliyatul Muna \\ Dosen Institut Agama Islam Negeri Ponorogo \\ izzaaliyatul@gmail.com
}

\begin{abstract}
Abstrak
Pentingnya sistem penilaian yang dapat mengukur kemampuan siswa secara kognitif, afektif, dan psikomotorik maka diperlukan suatu asesmen yang dapat mengukur hasil belajar siswa yang tidak hanya bisa diukur dengan nilai melalui tes tertulis, jadi agar kualitas pembelajaran dapat berkembang lebih baik maka dibutuhkan asesmen portofolio yang merupakan bagian dari penilaian kelas yang saat ini dikembangkan. Portofolio merupakan kumpulan hasil karya siswa yang membutuhkan kinerja sesuai konteks, adapun contoh-contoh hal apa saja yang dapat dimasukkan siswa ke dalam portofolio adalah tes, hasil karya yang telah dievaluasi untuk tugas wajib siswa, tugas-tugas kinerja, dan proyek kerja seperti makalah atau tugas lainnya yang dibuat oleh siswa sendiri. Dengan menerapkan penilaian alternatif yaitu salah satunya penilaian portofolio terhadap siswa, dapat dikumpulkan bukti-bukti kemajuan siswa secara aktual yang dapat digunakan sebagai bahan pertimbangan untuk memperbaiki proses pembelajaran selanjutnya.Selain itu penilaian seperti ini dirasakan lebih adil dan transparan bagi siswa serta dapat meningkatkan motivasi siswa untuk terlibat secara aktif dalam proses pembelajaran.
\end{abstract}

Kata kunci: Asesmen Portofolio, Pembelajaran IPA, Sekolah Dasar

\begin{abstract}
The importance of a scoring system that can measure students' abilities cognitively, affectively and psychomotorically requires an assessment that can measure student learning outcomes that can not only be measured by value through written tests, so that the quality of learning can grow better then a portfolio assessment is required Part of the classroom assessment currently under development. A portfolio is a collection of students' work that requires context-specific performance, as for examples of what students can include in the portfolio are tests, evaluated work for compulsory student tasks, performance tasks, and work projects such as papers or Other tasks created by the students themselves. By applying an alternative assessment that is one of the assessment of the portfolio of students, can be collected evidence of student progress that can actually be used as a consideration to improve the next learning process. In addition, such assessment is felt more just and transparent for students and can increase student motivation To be actively involved in the learning process.
\end{abstract}

Keywords: Education, Islam, Globalization. 


\section{A. PENDAHULUAN}

Pembelajaran IPA di sekolah dasar merupakan pondasi awal dalam menciptakan siswa-siswa yang memiliki pengetahuan, keterampilan, dan sikap ilmiah. IPA (sains) merupakan salah satu konsep yang ditawarkan di sekolah dasar yang memiliki peran penting dalam pembentukan kepribadian intelektual anak. Umumnya masyarakat mengenal pembelajaran sains sebagai pola pembelajaran yang lebih banyak memberikan informasi tentang konsep-konsep materi sains berupa fenomena-fenomena alam atau lingkungan sekitar, dan juga terkait dengan prinsip-prinsip dan hukum-hukum dalam sains. Namun, jika pola pembelajaran hanya dalam bentuk memberikan informasi saja, maka siswa dapat terjebak dalam sistem pembelajaran yang hanya mengandalkan hafalan, sehingga siswa cenderung mudah bosan dengan sistem pembelajaran seperti ini. Oleh karena itu, penerapan asesmen merupakan salah satu bagian penting dalam suatu proses pembelajaran yang terkait dengan pencapaian hasil belajar siswa. Pola asesmen yang baik dapat memberikan kontribusi positif terhadap proses belajar mengajar dan akan berpengaruh pada hasil belajar siswa.

Berdasarkan hasil pengamatan di lapangan terutama terhadap pembelajaran sains di sekolah dasar, proses penilaian yang dilakukan selama ini semata-mata hanya menekankan pada penguasaan konsep (kognitif) yang dijaring dengan tes tulis obyektif dan subyektif sebagai alat ukurnya. Sehingga kondisi seperti ini menyebabkan guru kurang fokus pada pengembangan keterampilan proses anak dalam proses pembelajaran. Realitas ini mendorong siswa untuk menghapal pada setiap kali akan diadakan tes harian atau tes hasil belajar. Padahal menurut Marjono untuk siswa pada jenjang sekolah dasar yang harus diutamakan adalah bagaimana mengembangkan rasa ingin tahu dan daya kritis anak terhadap suatu masalah. ${ }^{1}$

Fenomena di atas menunjukkan bahwa sistem penilaian yang digunakan dalam mengukur hasil belajar siswa sangat berpengaruh terhadap strategi pembelajaran yang dirancang dan dilaksanakan oleh guru. Sistem penilaian yang benar adalah tentunya harus selaras dengan tujuan dan proses pembelajaran. Tujuan pembelajaran sains SD, dapat dirangkum ke dalam tiga aspek sasaran pembelajaran yaitu penguasaan konsep sains, pengembangan keterampilan proses/kinerja siswa, dan penanaman sikap ilmiah. Oleh karena itu agar informasi hasil belajar siswa dapat terungkap secara menyeluruh, maka diperlukan adanya pengukuran terhadap ketiga aspek tersebut di atas. Sehingga sasaran dari penilaian hasil belajar di SD meliputi semua komponen yang menyangkut proses dan hasil belajar siswa dalam kegiatan belajar mengajar dapat tercapai. Tentunya dibutuhkan alat penilaian alternatif yang diasumsikan dapat memenuhi hal tersebut diantaranya adalah tes kinerja atau performance test dan jenis penilaian alternatif lainnya seperti penilaian produk, portofolio, dan penilaian lainnya. Dimana menurut Stiggins dengan adanya performance test dapat meningkatkan kemampuan siswa

\footnotetext{
1 "Pendidikan: Asesmen dalam Pembelajaran Sains SD."
} 
dengan adanya kesempatan siswa untuk mendemonstrasikan keahlian yang dimilikinya, dan juga guru dapat memantau kemampuan siswa melalui karya-karya yang dihasilkan siswa, tentunya hal ini tidak didapatkan dengan tes yang hanya mengandalkan kertas dan pensil. ${ }^{2}$ Penilaian alternatif yaitu penilaian portofolio terhadap siswa, dapat dikumpulkan bukti-bukti kemajuan siswa secara aktual yang dapat digunakan sebagai bahan pertimbangan untuk memperbaiki proses pembelajaran selanjutnya. Menurut Marzano di dalam penilaian kinerja terdapat perbedaan tugas dan situasi yang diberikan kepada siswa serta memberikan kesempatan untuk mempelihatkan pemahamannya dan kebenarannya dalam aplikasi pengetahuan dan keterampilan menurut kebiasaan berfikirnya. $^{3}$

Kenyataan yang ditemukan di lapangan memperlihatkan adanya ketidaksesuaian antara pembelajaran sains di SD dengan sistem penilaian yang digunakannya, yaitu proses penilaian yang biasa dilakukan guru selama ini hanya mampu menggambarkan aspek penguasaan konsep peserta didik, sehingga tujuan kurikuler mata pelajaran sains belum dapat dicapai secara menyeluruh. Maka diperlukan suatu teknik penilaian yang mampu mengungkap aspek produk maupun proses. Sistem penilaian yang diasumsikan dapat memenuhi tuntutan tersebut adalah sistem penilaian seperti penilaian

\footnotetext{
${ }^{2}$ Stiggins, Student-centered classroom assessment, 160.

${ }^{3}$ Wulan, "Penggunaan asesmen alternatif pada Pembelajaran biologi."
}

penugasan, penilaian proyek, maupun penilaian portofolio. Penilaian berbentuk asesmen menuntut adanya kompetensi dan kreativitas serta inisiatif yang lebih luas dari diri siswa. Selain itu penilaian juga menyediakan informasi secara komprehensif mengenai kemajuan belajar siswa termasuk kekuatan dan kelemahannya. Namun, realitanya di lapangan masih banyak guru yang belum memahami tentang portofolio seutuhnya, dan juga belum bisa melaksanakan perencanaan yang baik dalam merancang penilaian portofolio. Hal ini terlihat dari penelitian Wulan yang meneliti tentang "Permasalahan yang Dihadapi dalam Pemberdayaan Praktikum Biologi di SMU dan Upaya Penanggulangannya", dimana hasil penelitiannya terlihat bahwa guru biologi masih kesulitan dalam menggunakan asesmen kinerja untuk menilai praktikum siswa. ${ }^{4}$ Penelitian lain juga ditemukan hal yang sama, seperti halnya Morgan yang merupakan peneliti dari The University of Texas menemukan bahwa lebih dari 70\% guru tidak menggunakan rubrik dalam melakukan penilaian portofolio. Selain itu adanya beban mengajar dan jumlah siswa yang tidak ideal dalam suatu kelas dapat juga menyulitkan guru dalam melaksanakan asesmen portofolio secara ideal. ${ }^{5}$

Salah satu assesmen yang dapat diterapkan pada pembelajaran khususnya pembelajaran sains di SD adalah assesmen portofolio yang dapat memperlihatkan aspek kognitif, afektif, dan psikomotor siswa dalam proses belajar mengajar. Menurut Arends, portofolio merupakan

\footnotetext{
${ }^{4}$ Ibid.

${ }^{5}$ Morgan, "Research-based instructional strategies."
} 
kumpulan hasil karya siswa yang membutuhkan kinerja sesuai konteks, adapun contoh-contoh hal apa saja yang dapat dimasukkan siswa ke dalam portofolio adalah tes, hasil karya yang telah dievaluasi untuk tugas wajib siswa, tugas-tugas kinerja, dan proyek kerja seperti makalah atau tugas lainnya yang dibuat oleh siswa sendiri. ${ }^{6}$

\section{B. PENDIDIKAN SAINS DI SEKOLAH DASAR}

Sains atau Ilmu Pengetahuan Alam berhubungan dengan bagaimana mencari tahu tentang alam secara sistematis. Sebab, sains bukan hanya penguasaan kumpulan pengetahuan berupa faktafakta, konsep-konsep atau prinsip-prinsip saja tetapi juga merupakan proses penemuan. ${ }^{7}$ Oleh karena itu pendidikan sains tidak terlepas dari pengembangan keterampilan dan sikap-sikap yang diperlukan untuk mencapai suatu pengetahun. Tujuan-tujuan tersebut sesuai dengan hakikat sains itu sendiri. Seperti yang dikemukakan oleh Darmojo yaitu sains sebagai produk dan sains sebagai proses. Sains sebagai produk adalah prinsip-prinsip, teori-teori hukum, konsep-konsep maupun fakta yang semuanya itu ditujukan untuk menjelaskan berbagai gejala alam. Sedangkan sains sebagai proses adalah proses mendapatkan ilmu itu sendiri. ${ }^{8}$

Pembelajaran sains sebaiknya dilakukan secara inkuiri ilmiah (scientific inqury). Hal ini untuk menumbuhkan kemampuan berfikir, bekerja, dan

\footnotetext{
${ }^{6}$ Arends, Learning to teach.

${ }^{7}$ Depdiknas, "Kurikulum Tingkat Satuan Pendidikan (KTSP) Untuk Sekolah Dasar/ MI."

${ }^{8}$ Darmodjo dan Kaligis, Pendidikan IPA II, 5.
}

bersikap ilmiah serta mengkomunikasikannya sebagai aspek penting kecakapan hidup. Oleh karena itu pembelajaran sains SD menekankan pemberian secara langsung melalui pengembangan keterampilan proses dan sikap ilmiah. Mengingat proses belajar dan penilaian saling berkaitan erat, maka agar siswa terdorong untuk mengembangkan daya kreasi dan keterampilan berfikirnya hendaknya penilaian yang dilakukan tidak hanya ditujukan pada aspek penguasaan konsep saja, namun perlu dilengkapi dengan penilaian terhadap proses belajar siswa atau aktivitas siswa, karya siswa, dan sikap siswa.

Adapun instrumen penilaian yang dapat digunakan untuk menilai kinerja siswa tersebut adalah dengan menggunakan penilaian berbasis asesmen (assessment based evaluation). Penilaian berbasis asesmen menuntut tertampilkannya kompetensi dan kreativitas serta inisiatif yang lebih luas dari diri siswa. Sebagaimana yang dikemukakan oleh Khattri, bahwa penilaian terhadap berbagai aspek kinerja siswa memiliki pengaruh positif di kelas, karena melengkapi guru dengan acuan pedagogis yang membantu mengembangkan teknik instruksional yang efektif, maka guru sebagai pengelola utama kegiatan pembelajaran diharapkan mampu memahami, merencanakan sekaligus melaksanakan berbagai jenis penilaian berbasis asesmen terutama yang dapat diterapkan dalam pembelajaran sains di sekolah dasar.

\section{PENGAJARAN DAN EVALUASI}

Evaluasi merupakan bagian penting dan juga integral dari keseluruhan 
kegiatan belajar-mengajar, dimana dengan kata lain evaluasi saling terkait erat dengan komponen-komponen lain dalam proses pengajaran. Menurut Purwanto evaluasi yang dilakukan secara tidak benar dapat mematikan semangat siswa dalam belajar, sebaliknya evaluasi yang dilakukan dengan baik dan benar seharusnya dapat meningkatkan mutu dan hasil belajar siswa. Jadi dengan adanya evaluasi dapat membantu guru dalam memperbaiki kualitas dan cara mengajar serta dapat menyemangati siswa dalam belajar. ${ }^{9}$

Secara tidak langsung asesmen tidak dapat dipisahkan dari proses pengajaran. Hal ini dikemukakan oleh Gronlund yang menyatakan bahwa penilaian (assesment) dan pengajaran (instruction) merupakan dua hal yang saling mendukung dalam proses pembelajaran, sehingga kegiatan belajarmengajar yang efektif membutuhkan pengembangan kita dalam mengelola pembelajaran yaitu terkait dengan bagaimana kita mengajar, pengorganisasian dalam melaksanakan KBM dan tentunya terkait dengan proses asesmen yang merupakan hal yang sangat mendasar dalam suatu proses pembelajaran karena akan berpengaruh terhadap metode belajar siswa dan juga terhadap sikap siswa. ${ }^{10}$

Secara istilah, evaluasi memiliki beberapa pengertian yang hampir sama. Menurut Wand dan Brown evaluasi merupakan suatu tindakan atau suatu proses untuk menentukan nilai dari

\footnotetext{
${ }^{9}$ Purwanto, Prinsip-prinsip dan teknik evaluasi pengajaran, 80.

${ }^{10}$ Gronlund, Assessment of student achievement, 4.
}

sesuatu. Jadi terkait dengan pendidikan, evaluasi dapat diartikan sebagai suatu tindakan atau proses dalam menentukan nilai dan mutu suatu pendidikan. ${ }^{11}$ Sedangkan menurut Sudjana penilaian merupakan proses memberikan atau menentukan nilai kepada obyek tertentu berdasarkan suatu kriteria tertentu. ${ }^{12}$

Dalam kaitannya dengan kegiatan pengajaran, evaluasi menurut Gronlund merupakan suatu proses yang sistematis untuk menentukan atau membuat keputusan sampai sejauh mana tujuantujuan pengajaran telah dicapai oleh siswa. ${ }^{13}$ Adapun aspek-aspek yang dinilai dalam proses pengajaran harus mengacu terhadap aspek kognitif, afektif dan psikomotor siswa, hal ini sejalan dengan pendapat Dockrell yang menyatakan bahwa pendidikan tidak hanya terkait dengan pengetahuan (kognitif) dan ketrampilan (psikomotor) tetapi juga terkait dengan sikap (afektif). ${ }^{14}$ Berdasarkan permasalahan tersebut maka dibutuhkan penilaian alternatif dalam melakukan penilaian terhadap hasil belajar siswa, dimana menurut Anderson menyatakan bahwa penilaian yang digunakan di kelas merupakan pengembangan dari guru itu sendiri yang meliputi hal-hal yang lebih jauh daripada koleksi-koleksi tertulis karena dengan menggunakan observasi dan hasil karya siswa dalam proses penilaian dapat memberikan informasi yang penting terkait proses pembelajaran. ${ }^{15}$

\footnotetext{
${ }^{11}$ Sudijono, Pengantar evaluasi pendidikan, 1-2.

${ }^{12}$ Sudjana, Penilaian hasil proses belajar mengajar.

${ }^{13}$ Purwanto, Prinsip-prinsip dan teknik evaluasi pengajaran.

${ }^{14}$ Desforges, Introduction to Teaching.

${ }^{15}$ Anderson, The effective teacher, 377.
} 


\section{ASESMEN PORTOFOLIO}

Secara etimologi, portofolio berasal dari dua kata, yaitu port (singkatan dari report) yang berarti laporan dan folio yang berarti penuh atau lengkap, jadi portofolio bearti laporan lengkap segala aktivitas seseorang yang dilakukan. ${ }^{16}$ Sedangkan Paulson mengemukakan bahwa portofolio merupakan kumpulan hasil kerja siswa yang bermakna yang menunjukkan usahausaha, kemajuan dan pencapaian siswa pada satu bidang atau lebih. Dimana kumpulan tersebut harus memuat partisipasi siswa dalam memilih bahan, kriteria pemilihan, kriteria untuk menentukan nilai, dan bukti-bukti dari refleksi diri siswa. ${ }^{17}$

Hal ini terlihat dalam penelitian Jantimala terlihat bahwa: 1. pembelajaran dengan menggunakan portofolio dapat meningkatkan hasil belajar dengan pencapaian rata-rata gain kelas eksperimen adalah 68\%; $2 . \quad$ pada pelaksanaan pembelajaran dengan menggunakan portofolio ditemui beberapa kendala dari siswa, guru, dan orang tua siswa; namun juga diperoleh bahwa 3. pada pelaksanan penelitian ini yaitu pembelajaran dengan menggunakan portofolio mendapat tanggapan positif dari siswa, guru, dan orang tua siswa. ${ }^{18}$

Jadi berdasarkan beberapa pendapat ahli dan beberapa hasil penelitian tersebut dapat di indikasikan bahwa portofolio merupakan suatu

\footnotetext{
16 “OJO DUMEH: PENILAIAN PORTOFOLIO.”

${ }^{17}$ Sugiyarti, "Penerapan Asesmen Portofolio dalam

Meningkatkan Hasil Belajar Biologi Siswa di

Madrasah Aliyah."

${ }^{18}$ Jantimala, "Pembelajaran Konsep Sistem

Koordinasi dengan Memanfaatkan Portofolio Siswa."
}

komponen yang dapat dijadikan alaternatif dalam penilaian karena merupakan suatu koleksi hasil karya siswa yang menunjukkan usaha dan perkembangan kemajuan belajar siswa dan memberikan informasi yang lengkap dan obyektif sehingga dapat membuat siswa termotivasi untuk meningkatkan hasil belajarnya. Adapun tujuan pemanfaatan portofolio saat ini sudah semakin luas, hal ini didasari oleh adanya prinsip kebermaknaan dan humanisme. Menurut Sujiono pengukuran hasil belajar melalui portofolio yang terkait dengan pengukuran hasil belajar melalui pengalaman harus dapat memenuhi kompetensi dan standar tertentu, dimana kompetensi menggambarkan sejumlah kemampuan yang harus dimiliki seseorang untuk melaksanakan suatu tujuan, tetapi standar lebih ditekankan pada kualifikasi seseorang dalam pekerjaan tersebut yang terkait dengan unjuk perbuatan, dengan memperlihatkan suatu tingkat keterampilan dan pemahaman peserta didik, mendukung tujuan pembelajaran serta dapat merefleksikan perubahan oleh peserta didik, guru dan orang tua. ${ }^{19}$

Berbeda dengan penilaian lainnya, keterlibatan peserta didik dalam penilaian portofolio merupakan sesuatu yang harus dikerjakan. Ada beberapa prinsip yang perlu diperhatikan dan dijadikan pedoman dalam penggunaan penilaian portofolio, diantaranya adalah: 1 . saling percaya, 2 . kerahasiaan bersama, 3. milik bersama, 4 . kepuasan dan kesesuaian, 5. penciptaan budaya mengajar, 6 . refleksi bersama, 7 .

\footnotetext{
${ }^{19}$ Sudijono, Pengantar evaluasi pendidikan.
} 
proses dan hasil. ${ }^{20}$ Dasim Budimansyah mengemukakan asesmen portofolio mengacu pada sejumlah prinsip dasar penilaian, yaitu: 1 . prinsip penilaian proses dan hasil, 2. prinsip penilaian berkala dan berkesinambungan, 3. prinsip penilaian yang adil, dan 4. prinsip penilaian implikasi sosial belajar. ${ }^{21}$

Asmawi Zainul dan Agus Mulyana berpendapat, terdapat ada tiga prinsip utama dalam asesmen portofolio, yaitu mengkoleksi (collect), menseleksi (select), dan refleksi (reflect). Koleksi artinya dalam asesmen portofolio siswa mengumpulkan hasil-hasil kerjanya yang bisa disimpan dalam folder, box atau file. ${ }^{22}$ Seleksi artinya kumpulan hasil kerja itu diseleksi dalam rangka upaya penyempurnaan dan refleksi artinya siswa memberikan penilaian kembali terhadap hasil kerjanya sehingga dia akan tahu kelemahan dan kelebihan yang dimiliki daru tugas yang dilaksanakan.

\section{E. Karakteristik Asesmen Portofolio}

Menurut Mac Isaac dan Jacson terdapat lima karakteristik asesmen portofolio, yaitu: struktur, dokumentasi, pencatatan, kolaborasi, dan catatan reflektif. Struktur membantu siswa dalam menentukan jenis fakta-fakta yang dilibatkan. Dokumentasi hasil belajar adalah untuk menggambarkan evolusi dari belajar. Pencatatan secara selektif hasil ulangan dan prestasi selama pengujian. Kolaborasi dengan orang lain, merupakan proses latihan dan kerjasama. Catatan

\footnotetext{
${ }^{20}$ Surapranata dan Hatta, Penilaian Portofolio.

${ }^{21}$ Budimansyah, Model pembelajaran dan penilaian berbasis portofolio.

${ }^{22}$ Mulyana, "PENILAIAN DAN ASESMEN

DALAM PEMBELAJARAN IPA."
}

reflektif adanya catatan setiap bagian fakta disertai dengan suatu penjelasan. ${ }^{23}$

Pengalaman yang ditulis Neiman bahwa hasil tugas-tugas siswa dikumpulkan dalam satu map, kemudian di akhir semester diserahkan pada siswa. Sehingga siswa dapat melihat dan menilai dirinya sendiri dan dapat mengidentifikasi tentang apa yang telah dipelajarinya dan dapat dengan jelas mengemukakan apa yang diinginkan untuk masa yang akan datang.

Menurut pendapat Faichmey, karakteristik portofolio adalah: 1 . menggambarkan perkembangan kemajuan anak dalam satu bidang secara lebih komprehensif, 2. memberi kesempatan bagi anak untuk memilih dan melakukan "self evaluation", 3. sebagai bukti autentik yang menggambarkan kemampuan belajar anak, 4. meningkatkan refleksi diri dan penilaian diri siswa, 5. sebagai alat dalam proses belajar mengajar yang menjembatani dan memudahkan dialog antara guru dan siswa. ${ }^{24}$

Asmawi Zainul dan Agus Mulyana berpendapat, karakteristik asesmen portofolio, adalah 1 . asesmen yang menuntut ditunjukkan hasil kerja sama antara guru dan siswa, 2. asesmen portofolio tidak sekedar kumpulan hasil karya siswa tetapi yang terpenting adalah adanya proses seleksi yang didasarkan kriteria, 3. asesmen portofolio mengumpulkan hasil karya siswa dari waktu ke waktu. Koleksi karya tersebut

\footnotetext{
${ }^{23}$ Barnett, "Portfolio use in educational leadership preparation programs," 101-2.

${ }^{24}$ Maryani, "Pembelajaran Kooperatif Gi (Group Investigation) Berbantuan Media Laboratorium Virtual Dilengkapi Handout Untuk Meningkatkan Kualitas Proses Dan Hasil Belajar."
} 
digunakan oleh siswa untuk melakukan refleksi sehingga dalam prosesnya asesmen portofolio merupakan suatu asesmen diri yang memungkinkan siswa dapat mengenal kekuatan dan kelemahan sendiri. Kelemahan-kelemahan tersebut dapat digunakan sebagai tujuan proses pembelajaran berikutnya, 4 . kriteria penilaian hasil karya harus jelas baik bagi guru siswa, dan diterapkan secara konnsisten. ${ }^{25}$

Menurut Barton dan Collin ada beberapa karakteristik esensial dalam pengembangan portofolio, yaitu: 1 . multi sumber, 2. authentic, 3. dinamis, 4. eksplisit, 5. integrasi, 6. kepemilikan, 7. beragam tujuan. ${ }^{26}$ Jadi, asesmen portofolio yang merupakan kumpulan hasil karya siswa haruslah disusun berdasarkan suatu standar tertentu dimana jenis tugas tersebut dikelompokkan menjadi beberapa bagian. Oleh karena itu, menurut Barton dan Collins ada 4 macam jenis evidence atau objek portofolio yang harus dikumpulkan siswa, yaitu: hasil karya peserta didik yaitu hasil kerja peserta didik yang dihasilkan dalam kelas, hasil kerja peserta didik yang dikerjakan di luar kelas, pernyataan dan hasil pengamatan yang dilakukan oleh guru atau pihak lainnya tentang peserta didik, dan hasil kerja peserta didik yang dipersiapkan khusus untuk portofolio. 27

\footnotetext{
${ }^{25}$ Mulyana, "PENILAIAN DAN ASESMEN DALAM PEMBELAJARAN IPA."

${ }^{26}$ Ibid., 82-90.

${ }^{27}$ Barnett, "Portfolio use in educational leadership preparation programs," 20.
}

\section{F. Keunggulan dan Kelemahan Asesmen Portofolio}

Belajar merupakan proses yang panjang, untuk memperoleh pengetahuan yang mendalam tentang sesuatu, siswa memerlukan banyak pengalaman (banyak membaca, banyak merenungkan, banyak komunikasi, memecahkan banyak masalah, dan sebagainya). Pembentukan gambar tentang kompetensi siswa juga memerlukan berbagai instrumen penilaian. Portofolio yang berisi koleksi produk siswa, dan laporan proses yang dilalui oleh siswa, yang meliputi rentang waktu yang panjang, dapat memberikan gambaran yang relatif lengkap tentang perkembangan dan kompetensi siswa yang bersangkutan. Wina Sanjaya mengemukakan keunggulan penggunaan portofolio dalam penilaian, adalah 1 . penilaian portofolio dapat menilai kemampuan siswa secara menyeluruh, 2. penilaian portofolio dapat menjamin akuntabilitas, 3. penilaian portofolio merupakan penilaian yang bersifat individual, 4. penilaian portofolio merupakan penilaian yang terbuka, 5. penilaian portofolio bersifat self evaluation. ${ }^{28}$

Gronlund berpendapat, portofolio memiliki beberapa keuntungan, antara lain sebagai berikut: 1 . kemajuan belajar siswa dapat terlihat dengan jelas, 2 . penekanan pada hasil pekerjaan terbaik siswa memberikan pengaruh positif dalam belajar, 3. membandingkan pekerjaan sekarang dengan yang lalu memberikan motivasi yang lebih besar dari pada membandingkan dengan milik orang lain,

\footnotetext{
${ }^{28}$ Sanjaya, Pembelajaran dalam implementasi kurikulum berbasis kompetensi.
} 
4. keterampilan asesmen sendiri dikembangkan mengarah pada seleksi contoh pekerjaan dan menentukan pilihan terbaik, 5. memberikan kesempatan siswa bekerja sesuai dengan perbedaan individu (misalnya siswa menulis sesuai dengan tingkat level mereka tetapi sama-sama menuju tujuan umum), 6. dapat menjadi alat komunikasi yang jelas tentang kemajuan belajar siswa bagi siswa itu sendiri, orang tua, dan lainnya. ${ }^{29}$

Kelemahan dari penilaian portofolio adalah 1. penggunaan portofolio tergantung pada kemampuan siswa dalam menyampaikan uraian secara tertulis. Selama siswa belum lancar berbahasa tulis Indonesia, penggunaan portofolio akan merupakan beban tambahan yang memberatkan sebagian besar siswa, 2 . penggunaan portofolio untuk penilaian memerlukan banyak waktu dari guru untuk melakukan penskoran, apalagi kalau kelasnya besar. Kelemahan lain penggunaan penilaian portofolio adalah: 1 . memerlukan waktu dan kerja keras bagi guru dibandingkan penilaian lain, 2 . penilaiaan portofolio memerlukan perubahan cara pandang baik dari guru itu sendiri, dari masyarakat termasuk perubahan cara pandang orang tua, 3 . penilaian portofolio memerlukan perubahan gaya belajar, 4. penilaian portofolio memerlukan perubahan sistem pembelajaran. ${ }^{30}$ Selain itu dalam menggunakan asesmen portofolio juga dibutuhkan pemahaman dan kreatifitas guru dalam merencanakan portofolio. Namun dalam penelitian Wulan dan

\footnotetext{
${ }^{29}$ Gronlund, Assessment of student achievement, 158.

${ }^{30}$ Sanjaya, Pembelajaran dalam implementasi kurikulum berbasis kompetensi, 201.
}

Iskandar terungkap bahwa para guru masih mengalami kesulitan dalam menyusun dan menggunakan asesmen alternatif yaitu asesmen portofolio.

Jadi, penggunaan portofolio dalam proses pembelajaran memiliki beberapa langkah-langkah penting yang harus diperhatikan dan dilakukan oleh guru, diantaranya yaitu; 1 . memastikan bahwa siswa memiliki berkas portofolio, 2 . menentukan bentuk dokumen atau hasil pekerjaan yang perlu dikumpulkan, 3 . siswa mengumpulkan dan menyimpan dokumen dan hasil pekerjaannya, 4. menentukan kriteria penilaian yang digunakan, 5. mengharuskan siswa menilai hasil pekerjaannya sendiri secara berkelanjutan, 6. menentukan waktu dan menyelenggarakan pertemuan portofolio, 7. melibatkan orang tua dalam proses penilaian portofolio. ${ }^{31}$

\section{G. Perencanaan Asesmen Portofolio}

Perencanaan dapat diartikan sebagai hubungan antara apa yang ada sekarang (what is) dengan bagaimana seharusnya (what should be) yang bertalian dengan hubungan, penentuan, tujuan, prioritas, program, dan alokasi sumber. ${ }^{32}$ Oleh karena itu seorang guru harus dapat menentukan atau membuat suatu perencanaan yang baik ketika akan menerapkan suatu model atau metode baik dalam pembelajaran maupun dalam sistem penilaiannya, agar siswa merasa nyaman dalam pembelajaran dan dapat meningkatkan hasil belajarnya.

\footnotetext{
${ }^{31}$ Popham dan Popham, Classroom assessment.

${ }^{32}$ Erla Dewi, "Implementasi Asesmen Hasil Belajar Menggunakan Penilaian Kelas Dalam Pembelajaran Kimia di SMA Kota Tanjung Balai Karimun,.”
} 
Perencanaan yang dapat dilakukan guru ketika akan menggunakan portofolio dalam pembelajaran dapat dilakukan di awal semester dengan membuat perangkat pembelajaran yang dimulai dengan pembuatan program tahunan, program semester, silabus sampai rencana pelaksanaan pembelajaran. Untuk dapat membuat perangkat pembelajaran tersebut, seorang guru harus mengetahui tahapan-tahapan penyusunan portofolio. Menurut Marheni, agar penggunaan portofolio dapat terarah, maka dibutuhkan enam (6) langkah perencanaan portofolio, yaitu: 1. menentukan fokus portofolio; 2 . menentukan aspek isi yang dinilai; 3 . menentukan bentuk susunan portofolio; 4 . menentukan penggunaan portofolio; 5. menentukan cara menilai portofolio; dan 6. menentukan penggunaan rubrik. ${ }^{33}$

\section{H. Pelaksanaan Asesmen Portofolio}

Tahapan selanjutnya dalam penerapan asesmen portofolio dalam pembelajaran adalah tahap pelaksanaan atau implementasinya dalam proses pembelajaran. Pada tahapan ini guru dapat memulainya dengan mengkomunikasikan kepada siswa terkait akan digunakannya asesmen portofolio, hal ini dapat dilakukan dengan mengumumkan tujuan dan fokus pembelajaran, selanjutnya guru dapat membuat kesepakatan prosedur pelaksanaan asesmen portofolio dengan siswa dimulai dari menentukan jenis tugas yang harus dikumpulkan sampai dengan menentukan kriteria penilaian. Menurut Wulan ada beberapa tahapan yang dapat dilakukan guru dalam melaksanakan

\footnotetext{
${ }^{33}$ MARHAENI, "Asesmen portofolio dalam pembelajaran berbasis kompetensi."
}

asesmen portofolio, yaitu: 1. guru dan siswa secara rutin mendiskusikan proses pembelajaran yang menuntun siswa menghasilkan karyanya; 2. guru mengumpulkan pekerjaan siswa untuk diperiksa dan diberi komentar, siswa dapat memperbaiki tugasnya bila masih memilki banyak kekurangan; 3. tugas atau catatan tentang siswa diberi tanggal dan dimasukkan ke dalam folder secara kronologis sesuai urutan waktunya; 4. guru memberikan umpan balik secara berkesinambungan terhadap siswa, sehingga siswa dapat senantiasa memperbaiki kelemahannya. Guru dapat memeriksa kembali pekerjaan siswa sesuai urutan waktu, melihat kemajuan belajarnya dan mengkaji taraf pencapaian kompetensi belajar siswa. Selanjutnya guru dapat memberi catatan tentang prestasi dan kemajuan belajar siswa, hasil catatan guru dilampirkan pada portofolio siswa; 5. kegiatan diskusi antara guru dan siswa hendaknya diupayakan untuk memberikan penilaian, namun digunakan untuk memunculkan kekuatan karya siswa; dan f. seleksi terhadap karya yang dilakukan oleh siswa dengan bantuan guru. Dalam hal ini siswa dapat memilih seluruhnya, sebagian atau hanya karya terbaik saja yang dimasukkan dalam portofolio mereka. ${ }^{34}$

Lebih lanjut Zainul mengemukakan bahwa ada beberapa hal yang harus dilalui dalam mengimplementasikan asesmen portofolio yaitu: 1. Tahap Persiapan, mengidentifikasi tujuan pembelajaran yang akan diakses dengan asesmen portofolio, menjelaskan kepada anak

\footnotetext{
${ }^{34}$ Wulan, "Penggunaan asesmen alternatif pada Pembelajaran biologi."
} 
bahwa akan dilaksanakan asesmen portofolio untuk mengakses tujuan pembelajaran dan memberikan contoh portofolio yang pernah dilaksanakan, menjelaskan bagian mana dan seberapa banyak kinerja dan hasil kerja akan disertakan portofolio, dalam bentuk apa dan bagaimana kinerja atau hasil kerja itu diakses, dan menjelaskan bagaimana kinerja dan hasil karya tersebut harus disajikan. 2. Tahap Pelaksanaan, guru melaksanakan proses pembelajaran dan selalu memotivasi anak untuk belajar, guru melakukan pertemuan secara rutin dengan anak guna mendiskusikan proses pembelajaran yang akan menghasilkan kerja anak sehingga setiap langkah anak dapat memperbaiki kelemahan yang mungkin terjadi, guru memberikan umpan balik secara berkesinambungan kepada anak, dan memamerkan keseluruhan hasil karya yang disimpan dalam portofolio. 3 . Tahap Penilaian, menegakkan kriteria penilaian yang dilakukan bersama-sama atau dengan partisipasi anak, kriteria yang telah disepakati diterapkan secara konsisten baik oleh guru maupun anak, arti penting dari tahap penilaian ini adalah self asesment yang dilakukan oleh anak sehingga anak menghayati dengan baik kekuatan dan kelemahannya dan hasil penilaian dijadikan tujuan baru bagi proses pembelajaran. ${ }^{35}$

Dalam melaksanakan asesmen portofolio sudah seharusnya guru merancang suatu skala penilaian atau disebut sebagai rubrik. Menurut Arends mengemukakan bahwa merancang scoring rubric yang baik merupakan salah satu

\footnotetext{
${ }^{35}$ Hasmalena, "Implementasi Asesmen Portofolio pada Anak Usia Dini."
}

aspek penting dalam performance assesment. Scoring rubric adalah deskripsi terperinci tentang tipe kinerja tertentu dan mengeksplisitkan kriteria yang akan digunakan untuk menilai kinerja. Secara umum scoring rubric terdiri dari dua tipe yaitu holistic rubric dan analytic rubric. ${ }^{36}$ Ketika guru akan menerapkan portofolio, maka dibutuhkan kreativitas guru dalam merancang rubrik, karena rubrik merupakan komponen penting bagi guru dalam menilai hasil karya portofolio yang siswa kumpulkan, adanya rubrik juga sangat penting dalam menilai kemampuan dan kualitas siswa dalam mengerjakan tugas-tugas portofolio yang telah disepakati sebelumnya.

\section{PENILAIAN HASIL BELAJAR SAINS}

Proses penilaian merupakan salah satu bagian penting yang harus dilakukan oleh pendidik untuk melihat kemampuan siswanya. Seperti yang dikemukakan oleh Firman dan Widodo penilaian merupakan proses pengumpulan dan pengolahan informasi dalam rangka membuat keputusan, dimana penilaian hasil belajar yang dilakukan oleh pendidik dilakukan secara berkesinambungan untuk memantau proses, kemajuan dan perbaikan hasil, yang dapat dilakukan dalam bentuk penugasan, ulangan harian, ulangan tengah semester, ulangan akhir semester, atau bentuk lain yang sesuai untuk mengukur ketercapaian standar kompetensi kelulusan peserta didik. ${ }^{37}$

$\begin{array}{cccc}\text { Jadi } & \text { dengan } & \text { kata lain } & \text { proses } \\ \text { penilaian } & \text { yang } & \text { dilakukan } & \text { guru }\end{array}$

\footnotetext{
${ }^{36}$ Arends, Learning to teach.

${ }^{37}$ Firman dan Widodo, Panduan pembelajaran ilmu pengetahuan alam SD/MI.
} 
berlangsung selama proses pembelajaran, dimana dengan adanya penilaian ini diharapkan siswa mampu meningkatkan kualitasnya dalam mempelajari dan mengimplementasikan materi yang didapatkan di sekolah. Selain itu setelah siswa mengikuti proses pembelajaran diharapkan adanya perubahan dalam kepribadian tingkah laku yang telah terbentuk dari keterampilan, kebiasaan, kemampuan, sikap, pemahaman konsep sehingga dapat meningkatkan prestasi belajar siswa. Hal tersebut juga dikemukakan oleh Anderson yang menyatakan bahwa belajar merupakan suatu proses perubahan yang relatif menetap terjadi dalam tingkah laku potensial sebagai hasil dari pengalaman.

Proses pelaksanaan penilaian hasil belajar peserta didik pada jenjang pendidikan dasar dan menengah yang dilaksanakan merujuk pada Standar Penilaian Pendidikan yaitu Peraturan Menteri Pendidikan Nasional Nomor 20 Tahun 2007 yang mencakup tujuh komponen, yaitu: pengertian istilah-istilah yang digunakan, prinsip penilaian, teknik dan instrumen penilaian, mekanisme dan prosedur penilaian, penilaian oleh pendidik, penilaian oleh satuan pendidikan, dan penilaian oleh pemerintah.

Realitas yang terlihat di lapangan saat ini penggunaan tes tertulis tidak dapat memunculkan kemampuan yang dimiliki peserta didik. Seperti yang diungkapkan oleh Firman dan Widodo bahwa semua kemampuan peserta didik dalam IPA tidak dapat diungkapkan secara baik terutama kemampuan afektif dan psikomotor. Hal ini terlihat dalam konteks penilaian hasil belajar peserta didik pada kelas awal di sekolah dasar dimana penilaian dengan tes tertulis dipandang kurang tepat karena siswa pada usia ini masih terkendala dengan membaca dan menulis, sehingga adanya proses penilaian dengan tertulis dianggap tidak valid dan kurang mampu menilai kemampuan hasil belajar peserta didik secara komprehensif. Oleh karena itu dengan menerapkan asesmen portofolio dalam penilaian sains diharapkan siswa memiliki kemampuan yang otentik yaitu siswa memiliki tingkat pengetahuan dan juga keterampilan yang konteksnya bisa lebih dekat dengan hal yang nyata dan dapat diaplikasikan dalam kehidupan mereka sehari-hari, selain itu dengan adanya penilaian alternatif seperti portofolio dapat membuat siswa lebih kreatif.

\section{J. KESIMPULAN}

Pembelajaran IPA di sekolah dasar merupakan pondasi awal dalam menciptakan siswa-siswa yang memiliki pengetahuan, keterampilan, dan sikap ilmiah. IPA (sains) merupakan salah satu konsep yang ditawarkan di SD yang memiliki peran penting dalam pembentukan kepribadian intelektual anak.Oleh karena itu penerapan asesmen merupakan salah satu bagian penting dalam suatu proses pembelajaran yang terkait dengan pencapaian hasil belajar siswa. Pola asesmen yang baik dapat memberikan kontribusi positif terhadap proses belajar mengajar dan akan berpengaruh pada hasil belajar siswa.

Proses pembelajaran IPA di SD menuntut keterlibatan peserta didik 
secara aktif dan bertujuan agar penguasaan dari kognitif, afektif, serta psikomotorik terbentuk pada diri siswa, maka alat ukur hasil belajarnya tidak cukup jika hanya dengan tes obyektif atau subyektif saja. Dengan cara penilaian tersebut keterampilan siswa dalam melakukan aktivitas baik saat melakukan percobaan maupun menciptakan hasil karya belum dapat diungkap. Demikian juga tentang aktivitas siswa selama mengerjakan tugas dari guru, baik berupa tugas untuk melakukan percobaan, peragaan maupun pengamatan.

Salah satu asesmen yang dapat diterapkan pada pembelajaran khususnya pembelajaran IPA di SD adalah assesmen portofolio yang dapat memperlihatkan aspek kognitif, afektif dan psikomotorik siswa dalam proses belajar mengajar. Portofolio merupakan kumpulan hasil karya siswa yang membutuhkan kinerja sesuai konteks, adapun contoh-contoh hal apa saja yang dapat dimasukkan siswa ke dalam portofolio adalah tes, hasil karya yang telah dievaluasi untuk tugas wajib siswa, tugas-tugas kinerja, dan proyek kerja seperti makalah atau tugas lainnya yang dibuat oleh siswa sendiri. Dengan menerapkan penilaian alternatif yaitu salah satunya penilaian portofolio terhadap siswa, dapat dikumpulkan buktibukti kemajuan siswa secara aktual yang dapat digunakan sebagai bahan pertimbangan untuk memperbaiki proses pembelajaran selanjutnya. Selain itu penilaian seperti ini dirasakan lebih adil dan transparan bagi siswa serta dapat meningkatkan motivasi siswa untuk terlibat secara aktif dalam proses pembelajaran.

\section{K. DAFTAR PUSTAKA}

Anderson, Lorin W. The effective teacher: study guide and readings. McGrawHill College, 1989.

Arends, Richard. Learning to teach. McGraw-Hill Higher Education, 2014.

Barnett, Bruce G. "Portfolio use in educational leadership preparation programs: From theory to practice." Innovative Higher Education 19, no. 3 (1995): 197 206.

Budimansyah, Dasim. Model pembelajaran dan penilaian berbasis portofolio. Genesindo, 2002.

Darmodjo, Hendro, dan Jenny RE Kaligis. Pendidikan IPA II. Jakarta: Depdikbud Dirjen Dikti P2TK, 1992.

Depdiknas. "Kurikulum Tingkat Satuan Pendidikan (KTSP) Untuk Sekolah Dasar/ MI." Depdiknas, 2006.

Desforges, Charles. Introduction to Teaching. Wiley-Blackwell, 1995.

Erla Dewi. "Implementasi Asesmen Hasil Belajar Menggunakan Penilaian Kelas Dalam Pembelajaran Kimia di SMA Kota Tanjung Balai Karimun,." Universitas Pendidikan Indonesia, 2008.

Firman, Harry, dan Ari Widodo. Panduan pembelajaran ilmu pengetahuan alam SD/MI. Jakarta: Pusat Perbukuan Depdiknas, 2008.

Gronlund, Norman E. Assessment of student achievement. ERIC, 1998. https://eric.ed.gov/?id=ED417221.

Hasmalena. "Implementasi Asesmen Portofolio pada Anak Usia Dini." Universitas Pendidikan Indonesia, 2009.

Jantimala. "Pembelajaran Konsep Sistem Koordinasi dengan Memanfaatkan Portofolio Siswa." Universitas Pendidikan Indonesia, 2007. 
MARHAENI, AA ISTRI N. "Asesmen portofolio dalam pembelajaran berbasis kompetensi." Sumber: http://www. undiksha. ac. id/elearning/staff/images/img_info /4/2-282. pdf, tgl 15 (2006). http://pasca.undiksha.ac.id/elearning/staff/images/img_info/4/ lt_5-282.pdf.

Maryani, Ika. "Pembelajaran Kooperatif Gi (Group Investigation) Berbantuan Media Laboratorium Virtual Dilengkapi Handout Untuk Meningkatkan Kualitas Proses Dan Hasil Belajar." Universitas Sebelas Maret, 2010. http://eprints.uns.ac.id/3272/1/1 30450508201002181.pdf.

Morgan, Bobbette M. "Research-based instructional strategies: Preservice teachers' observations of inservice teachers' use." In National Forum Journal, July, Vol. 2, 2004. http://www.nationalforum.com/El ectronic\%20Journal\%20Volumes/ Morgan,\%20Bobbette\%20M.\%20re search\%20Based\%20Instructional $\% 20$ Strategies $\% 20$ Preservice $\% 20 t$ eachers $\% 200$ bservations $\% 20$ of $\% 2$ OInservice\%20Teachers\%20Use.pd f.

Mulyana, Edi Hendri. "PENILAIAN DAN ASESMEN DALAM PEMBELAJARAN IPA." saung-guru 34 (2010). http://jurnal.upi.edu/saungguru/view/153/PENILAIAN\%20D AN\%20\%20ASESMEN\%20DALAM $\% 20$ PEMBELAJARAN\%20IPA.

“OJO DUMEH: PENILAIAN PORTOFOLIO." Diakses 7 Juni 2017. http://afifabdul.blogspot.co.id/201 0/12/penilaian-portofolio.html.

"Pendidikan: Asesmen dalam Pembelajaran Sains SD." Diakses 7 Juni 2017. http://meysiska.blogspot.co.id/200 9/05/asesmen-dalampembelajaran-sains-sd.html.

Popham, W. James, dan James W. Popham. Classroom assessment: What teachers need to know. Pearson/Allyn and Bacon, 2005.

Purwanto, M. Ngalim. Prinsip-prinsip dan teknik evaluasi pengajaran. Remaja Rosdakarya, 2000.

Sanjaya, Wina. Pembelajaran dalam implementasi kurikulum berbasis kompetensi. Kencana, 2006.

Stiggins, Richard J. Student-centered classroom assessment. Merrill New York, 1994. https://files.nwesd.org/depts/ead min/Admin_Website/CITCL/LiteratureReference/JournalArt icles/Student-Centered-ClassroomAssessment_Stiggins.pdf.

Sudijono, Anas. Pengantar evaluasi pendidikan. Jakarta: Raja Grafindo Persada, 2005.

Sudjana, Nana. Penilaian hasil proses belajar mengajar. Remaja Rosdakarya, 1990.

Sugiyarti. "Penerapan Asesmen Portofolio dalam Meningkatkan Hasil Belajar Biologi Siswa di Madrasah Aliyah." IKIP Bandung, 2000.

Surapranata, Sumarna, dan Muhammad Hatta. Penilaian Portofolio: Implementasi Kurikulum 2004. Bandung: Remaja Rosdakarya, 2006.

Wulan, Ana Ratna. "Penggunaan asesmen alternatif pada Pembelajaran biologi." Jurnal Perkembangan Biologi dan Pendidikan Biologi untuk Menunjang Profesionalisme Jurusan Pendidikan Biologi FPMIPA UPI, 2007.

http://103.23.244.11/Direktori/FP MIPA/JUR._PEND._BIOLOGI/ANA_R ATNAWULAN/asesmen_alternatif.p df. 